DOE/ER/60602--T2

DE9? 009094

\title{
Ocean Studies Board Annual Report 1989 And Future Plans
}

Ocean Studies Board

Commission on Geosciences, Environment, and Resources National Research Council

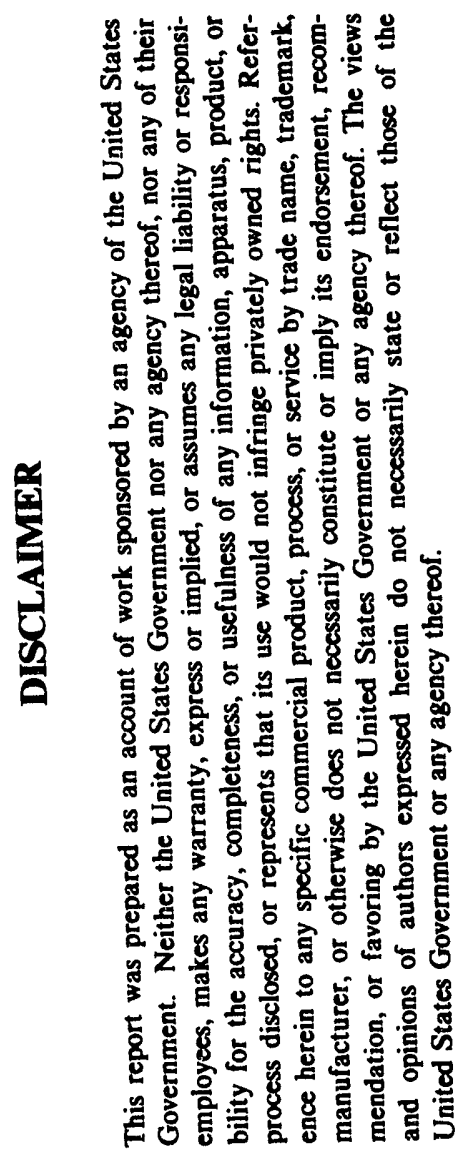

NATIONAL ACADEMY PRESS

Washington, D.C. 1990

\section{MASTER}

OISTRIBUTION OF THIS DOCUMENT IS UMLIMITED 
The Ocean Studies Board (OSB) was established in July 1985. It is a unit of the Commission on Geosciences, Environment, and Resources (CGER) of the National Research Council (NRC). The NRC serves as an independent advisor to the federal government on scientific and technical matters of national importance. Jointly administered by the National Academy of Sciences (NAS), National Academy of Engineering (NAE), and the Institute of Medicine (IOM), the NRC brings the resources of the entire scientific community to bear on national problems through its volunteer advisory committees.

This material is based on work supported by the National Science Foundation, the Office of Naval Research, the National Oceanic and Atmospheric Administration, the Department of Energy, the U.S. Geological Survey, the Department of State, the National Aeronautics and Space Administration, and the Environmental Protection Agency.

Copies available in limited quantity from

\section{OCEAN STUDIES BOARD}

National Research Council

2101 Constitution Avenue, N.W., HA 550

Washington, D.C. 20418

Printed in the United States of America 


\section{OCEAN STUDIES BOARD}

John G. Sclater, University of Texas at Austin, oceanography/geophysics, Chairman Robert D. Beardsley, Woods Hole Oceanographic Institution, physical oceanography Donald F. Boesch, Louisiana Universities Marine Consortium, ecology Peter G. Brewer, Woods Hole Oceanographic Institution, marine geochemistry Russ E. Davis. Scripps Institution of Oceanography, physical oceanography Robert Detrick, University of Rhode Island, marine physics Craig Dorman, Woods Hole Oceanographic Institution, physical oceanography Edward A. Frieman, Scripps Institution of Oceanography, acoustics Michael Glantz, National Center for Atmospheric Research, political science Arnold L. Gordon, Columbia University, physical oceanography Gordon Greve, Amoco Production Company, geophysics John I. Hedges, University of Washington, oceanography/geochemistry Eileen Hofmann, Old Dominion University, biological oceanography James J. O'Brien, Florida State University, physical oceanography John A. Orcutt, Scripps Institution of Oceanography, marine geophysics Dennis A. Powers, Stanford University, marine molecular ecology Michael P. Sissenwine, National Marine Fisheries Service, fisheries Karl K. Turekian, Yale University, marine chemistry

\section{Liaison Members}

D. James Baker, Jr., Joint Oceanographic Institutions, Inc., physical oceanography Walter H. Munk, Scripps Institution of Oceanography, physical oceanography

\section{Staff Members}

Mary Hope Katsouros, Staff Director Edward R. Urban, Jr., Staff Officer Maureen A. Hage, Administrative Secretary LaVoncye Mallory, Secretary 


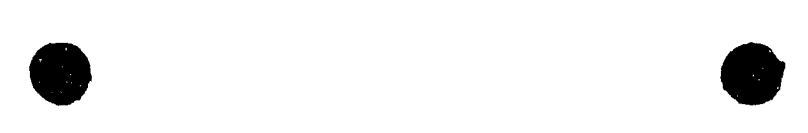

COMMISSION ON GEOSCIENCES, ENVIRONMENT, AND RESOURCES

M. Gordon Wolman, The Johns Hopkins University, Chairman

Robert C. Beardsley, Woods Hole Oceanographic Institution

B. Clark Burchfiel, Massachusetts Institute of Technology

Ralph J. Cicerone, University of California at Irvine

Peter S. Eagleson, Massachusetts Institute of Technology

Lawrence W. Funkhouser, Chevron Corporation (retired)

Gene E. Likens, New York Botanical Garden

Jerry D. Mahlman, National Oceanic and Atmospheric Administration

Scott M. Matheson, Parsons, Behle \& Latimer

Jack E. Oliver, Cornell University

Philip A. Palmer, E. I. du Pont de Nemours \& Company

Frank L. Parker, Vanderbilt University

Duncan T. Patten, Arizona State University

Denis J. Prager, MacArthur Foundation

Larry L. Smarr, University of Illinois at Urbana-Champain

Crispin Tickell, UK Mission to the United Nations

Karl K. Turekian, Yale University

Irvin L. White, New York State Energy Research and Development Authority

James H. Zumberge, University of Southern Californi !

Stephen Rattien, Executive Director

Stephen D. Parker, Associate Executive Director

Janice E. Greene, Assistant Executive Director

Jeanette Spoon, Financial Officer

Gaylene Dumouchel, Administrative Assistant 


\section{CONTENTS}

Background

Major Activities--1989 4

Navy Panel 4

$\mathrm{CO}_{2}$ Panel 5

Committee on the Ocean's Role in Global Change 6

$\begin{array}{ll}\text { Committee on the Coastal Ocean } & 7\end{array}$

$\begin{array}{ll}\text { Workshop on Issues of U.S. Marine Fisheries } & 9\end{array}$

The Continental Margins Workshop Committee 9

$\begin{array}{lr}\text { Future Plans } & 10\end{array}$

$\begin{array}{ll}\text { Workshop on Tactical Oceanography } & 10\end{array}$

Workshop on Contribution of Molecular Biological
Tools in Global Ocean Initiatives

$\begin{array}{ll}\text { The Continental Margins Initiative--Phase II } & 12\end{array}$

$\begin{array}{ll}\text { Ad Hoc Committee on Ocean Acoustics } & 12\end{array}$

International Scientific Conference on Joint

Global Ocean Flux Study (JGOFS) North Atlantic

Bloom Experiment

Forum on Oceanography from Space: Importance for Understanding Global Climate Change

$\begin{array}{lll}\text { I Memberships } & 15\end{array}$

II Meetings $\quad 18$

$\begin{array}{ll}\text { III Publications } & 20\end{array}$ 


\section{BACKGROUND}

The Ocean Studies Board (OSB) was formed in July 1985; Walter Munk served as its first Chairman. The OSB is a unit of the Commission on Geosciences, Environment, and Resources (formerly the Commission on Physical Sciences, Mathematics, and Resources (CPSMR) of the National Research Council (NRC). The NRC serves as an independent advisor to the federal government on scientific and technical matters of national importance. Jointly administered by the National Academy of Sciences (NAS), the National Academy of Engineering (NAE), and the Institute of Medicine (IOM), the NRC brings the resources of the entire scientific community to bear on national problems through its volunteer advisory committees.

John Sclater was appointed chairman of the Ocean Studies Board on July 1, 1988. The current membership of the board is shown on page iii.

The terms of reference for the OSB are as follows:

- to contribute to the advancement of scientific understanding of the ocean by maintaining continuous oversight of the health of ocean sciences and stimulating their progress;

- to foster the application of scientific knowledge to the wise use of the ocean and its resources;

- to provide leadership for the formulation of national and international marine policy and to clarify scientific issues that affect ocean policy; and

- to address scientific issues involved in cooperative international oceanographic research and to improve technical assistance.

Since its establishment, the OSB has monitored the status and needs of ocean sciences and has assisted U.S. government agencies in developing and maintaining strong programs of ocean research that 
are responsive to scientific opportunities and national and international interests.

The National Academy of Sciences is the U.S. organization adhering to the International Council of Scientific Unions (ICSU), In addition to its unions and commissions, ICSU has scientific committees, one of which is the Scientific Committee on Oceanic Research (SCOR). The OSB serves as the U.S. National Committee for SCOR and therefore ensures participation of the U.S. oceanographic research community in the meetings and in planning the activities of this organization and encourages international cooperation in research endeavors recommended by SCOR.

The Ocean Studies Board is a multidisciplinary body with representation from the fields of marine biology, marine chemistry, marine geology and geophysics, physical oceanography, and political science. The board carries out a great deal of its work through its committees, panels, and working groups. Members of the working groups are assembled to conduct specific studies; upon completion of their work the groups are discharged. Standing committees and panels provide more general oversight of certain areas of oceanography, continuing to function as long as there is a need and interest from the oceanographic community. Federal agencies with marine research programs have liaison representation at board meetings. Members of OSB and its committees and panels are selected from academic institutions, national laboratories, and industry on the basis of high professional qualifications. Members of the board are appointed for three-year terms, with their appointments staggered so that about one-third of the members are replaced each year. Approximately 75 distinguished persons currently serve on the OSB and/or its subgroups. (The structure of the board is shown in Figure 1, p. 3.)

The OSB meets two or three times annually to review its programs, to develop new initiatives, to provide a forum for presentation and discussion of federal oceanographic $R \& D$ programs, and to assist in the formulation of U.S. positions on matters brought before SCOR. The OSB also hosts numerous international meetings such as the World Ocean Circulation Experiment (WOCE), the Joint Global Ocean Flux Study (JGOFS), and the Ridge Interdisciplinary Global Experiments (RIDGE).

Eight federal agencies provided support for the continuing programs of the Ocean Studies Board in 1989: the National Oceanic and Atmospheric Administration (NOAA), the National Science Foundation 


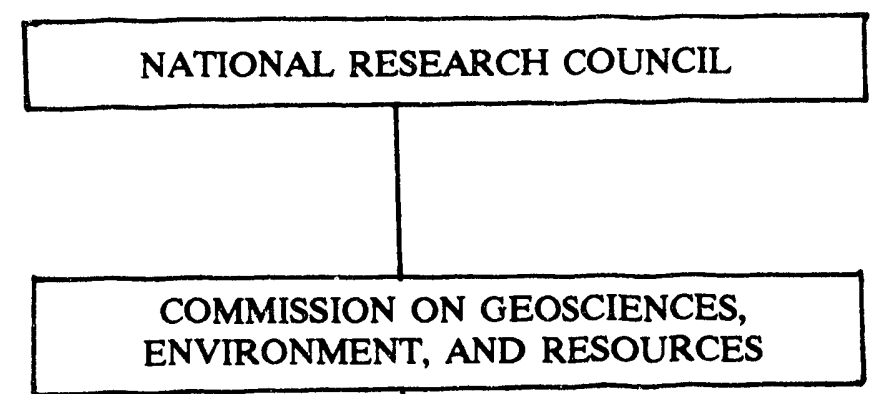

NAVY PANEL

NOAA PANEL

$\mathrm{CO}_{2}$ PANEL

COMMITTEE ON THE OCEAN'S ROLE IN GLOBAL CHANGE

COMMITTEE ON THE COASTAL OCEAN

CONTINENTAL MARGINS STEERING COMMITTEE

WORKSHOì ON U.S. MARINE FISHERIES STEERING COMMITTEE

U.S. NATIONAL COMMITTEE FOR THE SCIENTIFIC COMMITTEE ON OCEANIC RESEARCH

FIGURE 1 Structure of the Ocean Studies Board in 1989. 
(NSF), the Office of Naval Research (ONR), the National Aeronautics and Space Administration (NASA), the Department of Energy (DOE), the Environmental Protection Agency (EPA), the Department of State (DOS), and the U.S. Geological Survey (USGS). Core funding from the NSF also supports the board in its roles as the U.S. National Committee for SCOR. Supplementary support is also received from these agencies for specific studies; for example, the Continental Margins Workshop was funded by ONR, NSF, NOAA, DOE, and USGS. The board welcomes questions and suggestions about its programs and plans.

\section{MAJOR ACTIVITIES--1989}

During 1989, the board considered many issues confronting the ocean community. Several new initiatives were developed; they are discussed in the Future Plans section. A brief discussion of individual committee and panel activities during 1989 is presented below.

\section{Navy Panel}

This panel was established in 1985 to advise the Navy on the development of a long-range plan for ocean science R\&D, identify priority areas for Navy oceanographic research, review specific documents describing current and projected Navy programs, and respond to other requests for review and guidance. The panel was charged specifically with the following:

- to advise on the development of a long-range plan for Navy ocean sciences and development;

- to identify annually (and update if necessary) the leading priority areas on which Navy research is based: (1) current scientific opportunities and (2) Navy needs (These two areas are expected to change only gradually over a five-year period.);

- to review specific documents describing the current and projected Navy program; and

- to respond to other ad hoc requests for review and guidance as required. 
Following issuance of the panel's report entitled Oceanography and the Navy: Future Directions in 1988, the Director of the Office of Naval Research asked the Ocean Studies Board to undertake the following additional tasks:

- to identify promising research opportunities that are at the forefront of oceanic and related science and have high Navy relevance;

- to identify implications of marine data classification;

- to assist in the formulation of long-range ocean sciences ship use plans, especially the use of AGOR-23 and the Navy submersibles;

- to address manpower issues, including attracting quality students and quality scientists into Navy oceanography, and the future of the Secretary of the Navy Chairs;

- to identify approaches to improve utilization of existing oceanographic data;

- to assess whether infrastructure needs of the oceanographic community are being addressed adequately and how the Navy can contribute to these needs; and

- to recommend what the Navy can do to revitalize ocean acoustics in the university community.

The Navy Panel met five times in 1989 under the chairmanship of John Orcutt of the Scripps Institution of Oceanography.

In October 1989, the Navy Panel completed a letter report entitled "The Navy's Role in Global Change Research." This report contained advice to the Navy regarding its role in the growing national research effort surrounding world climate change. The report was prepared at the request of $\mathrm{Dr}$. Fred Saalfeld, Director of the Office of Naval Research.

$\underline{\mathrm{CO}}_{2}$ Panel

This panel was established in late 1987 to provide oversight and guidance regarding the scientific progress and plans for the investigation of the role of oceanic carbon, and related biogenic elements, in 
maintaining the Earth's planetary biogeochemical and climatic stability. For the past two years the panel has concentrated on the following matters:

- Data assimilation and modeling, including satellite issues.

- Ocean carbonate dissolution and climate feedback.

- Technologies and standards for measuring ocean $\mathrm{CO}_{2}$, radiocarbon, and organic carbon.

Peter Brewer chaired two meetings of the $\mathrm{CO}_{2}$ Panel during 1989. At the first meeting, because of the panel's concern about atmospheric $\mathrm{CO}_{2}$ calibrations, the National Institute of Standards and Technology was invited to give a presentation on its $\mathrm{CO}_{2}$ standards. At its second meeting, the panel decided to coordinate a series of papers on atmospheric and oceanic carbon measurements and standards. Additionally, the panel plans to convene one or two symposia inviting outside experts to address some of the important issues regarding atmospheric and oceanic $\mathrm{CO}_{2}$ concentrations. Topics to be included are: (1) measuring technologies with respect to organic carbon problems, (2) carbon-containing sediments, (3) air-sea gas exchange through the microlayer, and (4) general circulation models (GCMs) versus measurements.

The panel interacts with national and international working groups to ensure coordination of effort. At the next panel meeting, the progress of the WOCE carbon program will be discussed. The DOE is considering inviting the $\mathrm{CO}_{2}$ Panel to serve as advisors to the $\mathrm{DOE} \mathrm{CO}_{2}$ program.

\section{Committee on the Ocean's Role in Global Change}

The Committee on the Ocean's Role in Global Change was established in 1989 under the chairmanship of James O'Brien of Florida State University. The charge to this committee as follows:

- to identify the major physical, chemical, biological, and geological processes that are important in understanding the role of the ocean in global change; 
- to develop and prioritize the programs needed to significantly understand these processes.

- to study the desirability and feasibility of additional global ocean observation experiments to take place during the late 1990 s to measure, over an appropriate time period, the climatic state and motion of the world's oceans, and to estimate global change; and

- to serve as liaison between the U.S. ocean research community and the ICSU Committee on Climatic Changes and the Ocean (CCCO), consulting with and advising CCCO on U.S. programs and plans for ocean climate research as it relates to global change.

This committee plans to review major oceanographic programs to identify gaps and possible areas of cooperation and interaction in understanding climate change. Representatives of various programs-including the Atlantic Climate Change program, the Global Ocean Ecosystems Dynamics (GLOBEC) program, the Joint Global Ocean Flux Study (JGOFS), the Tropical Ocean-Global Atmosphere (TOGA) program and the World Ocean Circulation Experiment (WOCE)--describcd their plans and accomplishments at the October 1989 OSB meeting. The committee is currently preparing an article on these programs and their contribution to understanding global change. The comrrit se will work in cooperation with the Committee on Global Change of the National Research Council.

\section{Committee on the Coastal Ocean}

In response to increased scientific and public awareness of problems involving the coastal ocean, the OSB appointed a standing committee, the Committee on the Coastal Ocean ( $\mathrm{CoCO})$, to examine present coastal ocean research efforts and identify important research topics that are not being adequately addressed by various federal and state agencies. The standing committee evolved from a small ad hoc committee, chaired by Dr. John Costlow. The ad hoc committee outlined some fundamental questions involving research in the coastal environment and the degree to which various federal and state agencies were involved in coastal research. This ad hoc committee provided the OSB with a discussion paper that summarized their efforts and identified five very broad research questions: 
1. To what degree do different physical, geological, biological, and geochemical processes control the transport, transformation, and distributior ff materials in coastal waters?

2. To what degree and by what mechanisms do natural and anthropogenic changes in coastal waters affect the fluxes of materials and biological processes and populations?

3. To what degree are global material budgets affected or controlled by coastal processes?

4. To what degree will coastal processes be affected or controlled by changes in global balances?

5. To what degree and by what mechanisms do coastal organisms adapt to the physical, geochemical, and global changes outlined in questions 1 through 4 ?

The standing committee was expanded from 6 to 15 members in 1989 and, using the Costlow committee discussion paper, plans to hold a workshop in 1990 to bring together academic anis agency scientists and policy makers to define a coastal ocean research agenda.

The terms of reference for the $\mathrm{CoCO}$ are as follows:

- to contribute to the advancement of the scientific understanding of the coastal ocean, including continental margins, estuaries, and wetlands, by maintaining continuous oversight of the health of coastal sciences, and stimulate their progress;

- to foster the application of scientific knowledge to the conservation of the coastal environment and the wise use of its resources;

- to provide leadership for the formulation of national and regional coastal ocean policy and to clarify scientific issues that affect the coastal ocean; and

- to maintain close liaison with other NRC groups such as the Marine Board and the Board on Environmental Studies and Toxicology.

Rather than establish a new research initiative, the committee will provide a framework for the scientific community to (1) assess current and future research efforts in coastal ocean science, (2) identify 
missing components of present initiaives, and (3) facilitate a dialogue between appropriate parties concerning future research directions

\section{Workshop on Issues of U.S. Marine Fisheries}

On September 19-20, 1989, the Ocean Studies Boar . convened a workshop on Contemporary Issues of U.S. Marine Fisheries, attended by 11 external scientists and 9 NRC staff members. The purpose of the meeting was to determine if there was a consensus among fishery experts that an NRC study of fishery issues is needed, and if so, to determine its format and scope.

It was agreed that a proactive, comprehensive NRC study of fishery issues is needed. The Un: States does not have a national fisheries policy. The Magnuson Fishery Conservation and Management Act (MFCMA) of 1976 established a process for masagement of fish stocks, but there is wide latitude in its application. Furthermore, some fishery issues are beyond its scope. The NRC is uniquely qualified to conduct an objective study and produce a highiy crerible product that will be considered by legislative and agency policy makers.

Workshop participants identified several critical issues that should be considered as part of a study by the Ocean Studies Board: (1) biological and economic overfishing, (2) seafood trade, (3) enhancement of fisheries production through mariculture, (4) effect of habitat alteration on fish populations, (5) seafood safety, and (6) multiuse allocation issues.

\section{The Continental Margins Workshop Committee}

In 1988, the Ocean Studies Board, in conjunction with the Board on Earth Sciences and Resources, formed a committee chaired by C. Barry Raleigh to organize a workshop on continental margins. The workshop was attended by 72 scientists representing physical and chemical oceanography, geology, and geophysics.

Continental margins are the only record available of the long-term dynamic interaction of oceanic and continental lithosphere. The purpose of the workshop was to (l) define the state of knowledge of 
continental margins including structure, tectonics, and dynamics, (2) identify the areas in which research is poised to make dramatic progress, and (3) devise a plan to effect these advances during the next decade. A set of major scientific objectives was identified during the workshop, and there was consensus that a multidisciplinary, coordinated research program was the most efficient way to accomplish these objectives.

The proceedings of the workshop, The Margins Initiative: Interdisciplinary Studies of Processes Attending Lithospher istension and Convergence, will be published in early 1990 . As a result of the consensus among the workshop participants, recognizing the need for a science plan for margins research, a new initiative in continental margins research will be organized.

\section{FUTURE PLANS}

The Ocean Studies Board will continue to be the focus for the National Research Council to consider international and national ocean science issues. The OSB will serve as the linkage between the academic community and the federal agencies and will bring the leading U.S. scientific and engineering expertise to bear on its studies and related international activities. The OSB will provide guidance to federal agencies in the development and implementation of ocean science initiatives. Special meetings will be dedicated to discussion of agency ocean programs so that the entire membership of the Board can consider the important issues facing the federal agencies. The board will continue to serve as the U.S. National Committee for SCOR and will ensure participation of the U.S. oceanographic community in SCOR activities.

\section{Workshop on Tactical Oceanography}

At the request of Admiral Richard F. Pittenger, the Oceanographer of the Navy, a Workshop on Tactical Oceanography will be held in March 1990 at the Naval Postgraduate School in Monterey, California, which will be supported by the Office of the Oceanographer of the Navy and the Office of Naval Research and will be organized by OSB's Navy Panel. The workshop will provide an opportunity for discussions and 
an exchange of ideas between academic researchers and users of the research. The Navy Panel will organize this workshop. Approximately 125 individuals will be invited, half from the academic community and half from the military community. The workshop will be held at the secret level and will be organized around plenary sessions and working group meetings. Prior to the workshop, unclassified background papers will be prepared on the state-of-the-art in areas such as data bases and models. At the workshop, the working groups will prepare classified reports refining the analyses of the current status of the various areas and the relevance and use for the naval community. Additionally, an unclassified summary report will be prepared.

\section{Workshop on Contribution of Molecular Biological Tools to Address Global Ocean Initiatives}

There is wide agreement within the U.S. marine science community that an accelerated effort to apply biotechnological methods to marine sciences is desperately needed in order to keep our fundamental and applied research efforts competitive with other nations. A three-day meeting will be held in February 1990 to bring together marine molecular biologists and representatives of global oceanographic initiatives who could benefit from the new techniques, to reach a consensus about promising research directions. Meeting participants will determine the scope and content of a possible study of the current and future contributions of molecular biological techniques to the study of fundamental questions about marine processes. Such a study would focus particularly on regional and global processes, such as the carbon and nitrogen cycles and larval recruitment, where biotechnological methods could surmount current problems in understanding certain aspects of these processes. These techniques could play a key role in the success of several ocean science initiatives such as the Joint Global Ocean Flux Study (JGOFS) and the Global Oceans Ecosystems Dynamics (GLOBEC) experiment, as well as a number of other major programs initiated by various agencies. Use of a variety of biotechnological tools promises to revolutionize our knowledge of individual organisms as well as the population structure in the oceans. Dr. Dennis Powers, director of the Stanford University Hopkins Marine Station, will chair the planning meeting. 


\section{The Continental Margins Initiative--Phase II}

This initiative will consist of two workshops and will concentrate on defining and prioritizing specific programs of field work, laboratory measurements, and theoretical and computational studies. The objectives of the workshops will be to identify critical experiments for the study of processes at continental margins, culminating in a science plan that would present a strategy for implementing these experiments. The themes of the workshops will be Mechanics of Low-Angle Faulting and Fluids and Fluid Flow as Initiative I, and Magmatism and the Growth of Continental Crust and Continental Margin Sedimentary Record - Chaos to Continuity as Initiative II. Approximately 120 national and international scientists from academia, industry, and government agencies will be invited.

\section{Ad Hoc Subcommittee on Ocean Acoustics}

The Navy Panel formed an ad hoc Subcommittee on Ocean Acoustics because of a widespread concern that this important field is declining in terms of graduate student recruitment and funding, and that the potential contribution of ocean acoustics to answering basic oceanographic questions is not appreciated. The subcommittee, co-chaired by Drs. George 4 "Voods Hole Oceanographic Institution) and Terry Ewart (University of Washington), met for the first time in December 1989 and will hold two workshops in early 1990. The purpose of the workshops will be to define critical and exciting basic scientific questions in ocean acoustics and to make recommendations for improving graduate education in this discipline. The sorkshops will focus on water column acoustics, bottom acoustics, upper ocean wave scattering, and ambient noise. Participants at each workshop will consider how to stimulate graduate enrollment in ocean acoustics programs and how to improve these programs to avoid a scarcity of ocean acousticians in the future. The committee plans to submit its final report, synthesizing workshop material, by the end of 1990 . 
International Scientific Conference on Joint Global Ocean Flux Study (JGOFS)

North Atlantic Bloom Experiment

The Ocean Studies Board wi" host a three-day conference in September 1990 on the JGOFS North Atlantic bloom experiment. This multinational experiment monitored the annual phytoplankton bloom and related phenomena, from March through September 1989. One goal of the JGOFS program is to develop models of the orean carbon cycle that can be used to predict the uptake of anthropogenic $\mathrm{CO}_{2}$ by the oceans and the response of the ocean carbon cycle to climate changes such as those associated with increases in atmospheric greenhouse gases. This conference will bring together individuals from the national and international science communities interested in global change to discuss the findings and implications of the first JGOFS process experiment.

\section{Forum on Oceanography From Space: Importance for Understanding Global Climate Change}

A recurrent theme at the April 1989 Ocean Studies Board meeting concerned the difficulties that are arising because of delayed launch schedules of several satellite-based ocean sensors. Since that meeting the Sea-Viewing Wide Field of View Sensors (SeaWiFS), scheduled to be included on the Landsat 6 satellite to be launched in 1991, has been delayed. Two large-scale multinational ocean research projects (JGOFS and WOCE) are hampered by the launch delays, because these projects were planned as concurrent largescale synoptic measurements from satellites and detailed in situ measurements from ships. The SeaWiFS sensor would have enabled detection of phytoplankton productivity, a crucial component of the JGOFS effort. A similar situation has occurred with the delay of the TOPEX/Poseidon sensor scheduled on the European Space Agency ERS-1 satellite, which is important for correlations with direct observations of WOCE. The board expressed concern about the apparent lack of importance placed on the launch of these sensors, and the fact that several of the future sensors are scheduled to fly on foreign satellites, over which we will have limited control. A related issue is the continuing lack of a funding commitment for the Landsat 4 and 5 satellites, which are also important for global change research. 
The Ocean Studies Board proposes to convene a forum on the Importance of Oceanography from Space for Understanding Global Climate Change. This forum would bring together the leading academic and agency users and providers of satellite data, as well as leaders in the U.S. Congress, the National Space Council, and the National Academy of Sciences.

\section{LIAISON AND REPORT PUBLICATION}

The Ocean Studies Board works with other National Research Council groups concerned with ocean issues. Among these are the Polar Research Board, the Board on Atmospheric Sciences and Climate, the Board on Earth Sciences and Resources, and the Board on Environmental Studies and Toxicology, within the Commission on Geosciences, Environment, and Resources (formerly the Commission on Physical Sciences, Mathematics, and Resources); the Marine Board of the Commission on Engineering and Technical Systems; and the Board on Biology of the Commission on Life Sciences.

The Ocean Studies Board works with these groups to identify individuals to serve on committees formed to undertake special studies or to serve as qualified reviewers for study reports. The OSB invites presentations at its meetings on relevant activities of other NRC units and maintains liaisons with such activities. Some special studies are joint efforts between boards. The OSB also maintains close liaison with sponsoring agencies, foundations, and the public through formal and informal discussions, briefings, and notification of meetings.

Reports resulting from these efforts will be prepared in sufficient quantity to ensure distribution to the sponsor(s), OSB members, and other relevant parties in accordance with Academy policy. Reports may be made available to the public without restriction. When the board's supply has been exhausted, reports will be placed in the National Technical Information Service to ensure continuing availability. 


\section{APPENDIX I \\ OCEAN STUDIES BOARD MEMBERSHIPS}

\section{Navy Panel}

John Orcutt, Scripps Institution of Oceanography, marine geophysics, Chairman Craig Dorman, Woods Hole Oceanographic Institution, physical oceanography Peter Jumars, University of Washington, marine biology Walter Munk, Scripps Institution of Oceanography, oceanography, physics and biology James J. O'Brien, Florida State University, meteorology/physical oceanography John G. Sclater, University of Texas, Austin, oceanography/geophysics Robert C. Spindel, University of Washington, ocean acoustics

Oliver C. Zafiriou, Woods Hole Oceanographic Institution, geophysics/physical chemistry

\section{Ad Hoc Subcommittee on Ocean Acoustics, Navy Panel}

Terry Ewart, University of Washington, water column acoustics, Co-Chairman George Frisk, Pennsylvania State University, bottom acoustics, Co-Chairman Michael G. Brown, University of Miami, bottom acoustics David Farmer, Institute of Ocean Sciences, wave scattering Fred Fisher, University of California, La Jolla, radiation and ambient noise John McCoy, Catholic University of America, radiation and ambient noise

\section{$\underline{\mathrm{CO}}_{2}$ Panel}

Peter G. Brewer, Woods Hole Oceanographic Institution, chemical oceanography, Chairman Wayne E. Esaias, National Aeronautics and Space Administration, biological oceanography Richard H. Gammon, University of Washington, physical chemistry

James Hansen, National Aeronautics and Space Administration, atmospheric science Charles D. Keeling, Scripps Institution of Oceanography, marine chemistry

James J. McCarthy, Harvard University, biological oceanography

Berrien Moore, III, University of California, San Diego, mathematics

Roger R. Revelle, University of California, San Diego, oceanography Eric Sundquist, U.S. Geological Survey, marine geochemistry Taro Takahashi, Lamont-Doherty Geological Observatory, geochemistry David Walt, Tufts University, chemistry

Ray Weiss, Scripps Institution of Oceanography, geochemistry 


\section{Committee on the Ocean's Role in Global Change}

James J. O'Brien, Florida State University, meteorology/oceanography, Chairman

Richard T. Barber, Monterey Bay Aquarium Research Institute, biological oceanography

Tim P. Barnett, Scripps Institution of Oceanography, physical oceanography

Kenneth W. Bruland, University of California, marine geology/chemical oceanography

Arnold L. Gordon, Lamont-Doherty Geological Observatory, physical oceanography

Susan M. Henrichs, University of Alaska, chemical oceanography

Warren L. Prell, Brown University, marine geology/paleoceanography

John $\mathrm{H}$. Steele, Woods Hole Oceanographic Institution, biological oceanography

John Toggweiler, Princeton University, marine chemistry

\section{Committee on the Coastal Ocean}

Dennis Powers, Stanford University, molecular/physiological ecology, Co-Chairman

Donald F. Boesch, Louisiana Universities Marine Consortium, ecology, Co-Chairman

David G. Aubrey, Woods Hole Oceanographic Institution, marine geology

Robert Beardsley, Woods Hole Oceanographic Institution, physical oceanography

Biliana Cicin-Sain, University of Delaware, social sciences

John R. Costlow, Jr., Duke University, ecology

John Farrington, University of Massachusetts, marine chemistry

Eileen Hofmann, Old Dominion University, physical oceanography

Robert W. Howarth, Cornell University, terrestrial ecology

George A. Knauer, University of Southern Mississippi, marine chemistry

Scott W. Nixon, University of Rhode Island, ecology

James E. Overland, NOAA/PMEL, meteorology

Thomas M. Powell, University of California, Davis, physical oceanography

Jerry Schubel, State University of New York, marine geology

Michael P. Sissenwine, National Marine Fisheries Service, fisheries

\section{Workshop on Contemporary Issues of U.S. Marine Fisheries}

Michael P. Sissenwine, NOAA/NE Fisheries Center, fisheries management, Chairman

Dayton Lee Alverson, University of Washington, fisheries management, commercial fisheries

Roger Anderson, Cox's Wholesale Seafood, Inc., seafood trade, commercial fisheries

Nancy Bockstael, University of Maryland, fisheries economics

Jon M. Conrad, Cornell University, fisheries economics

John Mark Dean, University of South Carolina, fisheries habitat alteration, federal fishery regulations Cameron Hackney, Virginia Polytechnical Inst. and State University, seafood safety

Roger Mann, Virginia Institute of Marine Sciences, mariculture

Brian J. Rothschild, University of Maryland, fisheries management

William Royce, University of Washington, fisheries management

Donn Ward, North Carolina State University, seafond safety 


\section{Continental Margins Steering Committee}

C. Barry Raleigh, Columbia University, geophysics, Chairman James Austin, University of Texas, Austin, seismic stratigraphy, marine geology Mark Brandon, Yale University, geology, geophysics

Darrel Cowan, University of Washington, geology

Daniel Davis, State University of New York, geophysics

Suzanne Kay, Cornell University, petrology, marine geology

Gregory Moore, University of Hawaii, geology, geophysics

John Mutter, Lamont-Doherty Geological Observatory, marine seismology, geophysics

John Sclater, University of Texas, Austin, oceanography, geophysics

Brian Wernicke, Harvard University, structural technology, geology 

August 30-31

August 30

September $19-20$

October 18

October $19-20$

December 13

December 15

December 18-19
$\mathrm{CO}_{2}$ Panel Meeting, Monterey, CA

Committee on Coastal Oceans, Monterey, CA

Fisheries Meeting, Washington, D.C.

Navy Panel Meeting, Washington, D.C.

Ocean Studies Board, Washington, D.C.

Health of Ocean Science, Washington, D.C.

Ocean Acoustics, Washington, D.C.

Commission Meeting, Washington, D.C.

19 


\section{APPENDIX III \\ OCEAN STUDIES BOARD \\ PUBLICATIONS}

Greenland Sea Project (1987)

The Mid-Oceanic Ridge: A Dynamic Global System--Proceedings of a Workshop (1987)

Physical Oceanography for the Year 2000 (1987)

Recruitment Processes and Ecosysiem Structure of the Sea (1987)

Oceanography and the Navy--Future Directions (1988)

Ocean Studies Board Annual Report 1987 and Future Plans (1988)

Background Papers for the Workshop on Continental Margins: Evolution of Passive Continental Margins and Active Marginal Processes (1988)

Symposium Commemorating the 25th Anniversary of the Demonstration of the Feasibility of Deep Ocean Drilling (1989)

Ocean Studies Board Annual Report 1988 and Future Plans (1989)

Margins: A Research Initiative for Interdisciplinary Studies of Processes Attending Lithospheric Extensions and Convergence (1989)

The Navy's Role in Global Change Research (1989)

Copies of these reports can be obtained by contacting the Ocean Studies Board, 2101 Constitution Avenue, N.W., Washington, D.C. 20418. 

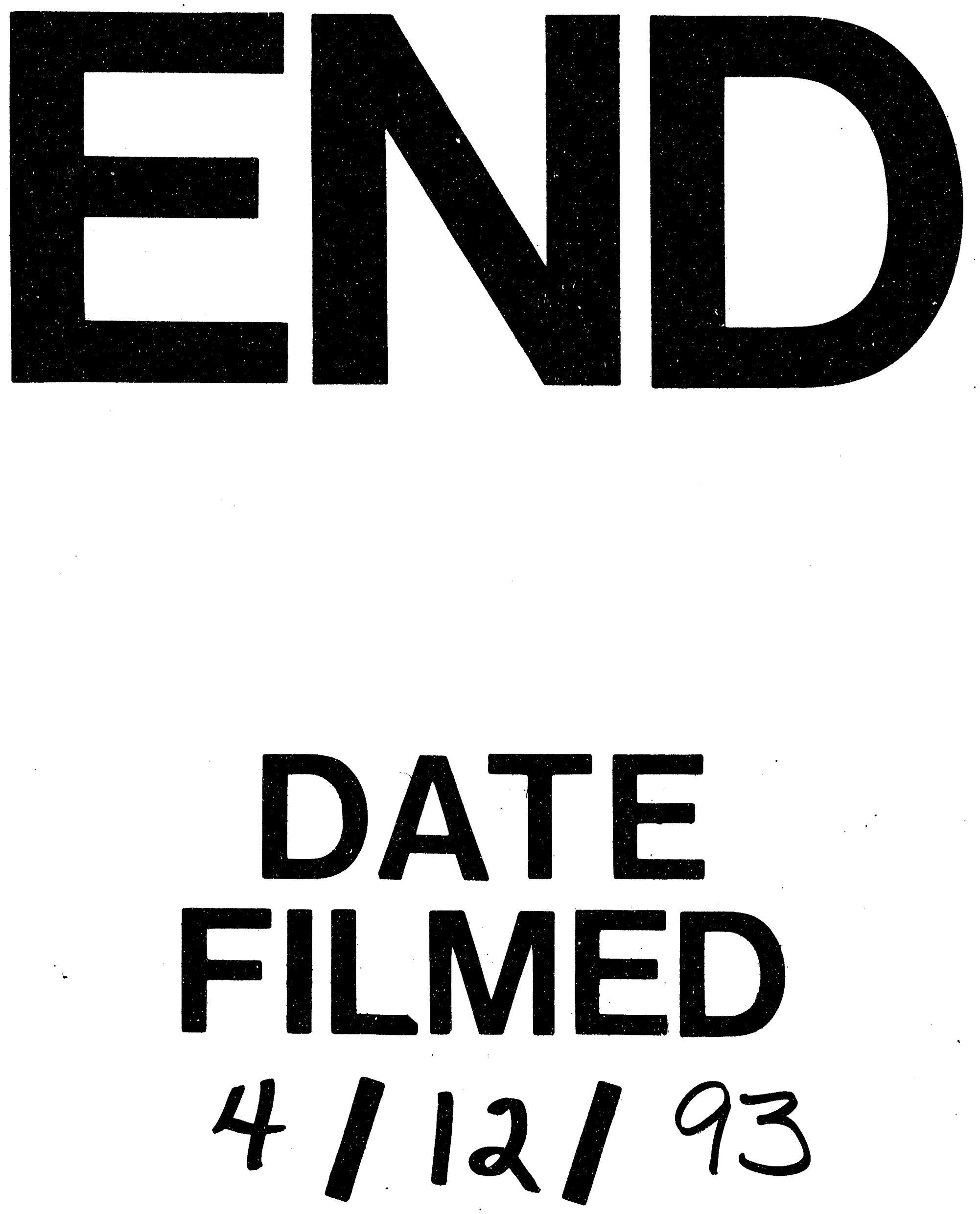